\title{
Remediation of Polluted River Water by Biological, Chemical, Ecological and Engineering Processes
}

\author{
Hossain Md Anawar ${ }^{1,2}$ and Rezaul Chowdhury ${ }^{3, *}$ (1) \\ 1 Department of Earth and Environmental Sciences, Faculty of Science and Engineering, Macquarie University, \\ Sydney 2109, Australia; anawar4@hotmail.com \\ 2 Asia-Pacific Science Center Pte. Ltd., Singapore 534818, Singapore \\ 3 School of Civil Engineering and Surveying, University of Southern Queensland, Toowoomba 4350, Australia \\ * Correspondence: rezaul.chowdhury@usq.edu.au; Tel.: +61-7-4631-2519
}

Received: 6 July 2020; Accepted: 24 August 2020; Published: 28 August 2020

check for updates

\begin{abstract}
Selection of appropriate river water treatment methods is important for the restoration of river ecosystems. An in-depth review of different river water treatment technologies has been carried out in this study. Among the physical-engineering processes, aeration is an effective, sustainable and popular technique which increases microbial activity and degrades organic pollutants. Other engineering techniques (water diversion, mechanical algae removal, hydraulic structures and dredging) are effective as well, but they are cost intensive and detrimental to river ecosystems. Riverbank filtration is a natural, slow and self-sustainable process which does not pose any adverse effects. Chemical treatments are criticised for their short-term solution, high cost and potential for secondary pollution. Ecological engineering-based techniques are preferable due to their high economic, environmental and ecological benefits, their ease of maintenance and the fact that they are free from secondary pollution. Constructed wetlands, microbial dosing, ecological floating beds and biofilms technologies are the most widely applicable ecological techniques, although some variabilities are observed in their performances. Constructed wetlands perform well under low hydraulic and pollutant loads. Sequential constructed wetland floating bed systems can overcome this limitation. Ecological floating beds are highly recommended for their low cost, high effectiveness and optimum plant growth facilities.
\end{abstract}

Keywords: polluted river water; water treatment; ecological restoration; constructed wetland; ecological floating bed; biofilm technology

\section{Introduction}

Pollution of river water is one of the biggest environmental problems, particularly in developing and underdeveloped countries. River water is the source of water for drinking and for domestic, agricultural, commercial, industrial and recreation uses. However, river water pollution in some countries is so severe that it cannot be used at all. Furthermore, it causes the spread of water borne diseases in many developing countries, emits severe and intolerable odours and pollutes the air. Water quality management depends on the strict policy controls for discharge of solid waste, wastewater, stormwater and standards of treated or untreated wastewater, which requires cost and time for successful execution [1]. Therefore, water management plans must consider sustainable strategies and policies for the successful remediation of polluted water [2].

\subsection{Sources of River Water Pollution}

Uncontrolled, unplanned, rapid and extensive growth of urbanisation and industrial activities generate large amounts of solid and liquid waste in urban areas. Disposal of untreated solid waste, 
stormwater and agricultural runoff, along with municipal and industrial wastewater, into the river is the main cause of physical, chemical (nutrients, metals, organic matters, nanomaterials, etc.) and microbial contamination of river water [3-5]. Sources of these wastes include industrial production, sewage, domestic waste, municipal waste, shopping markets, restaurants, agricultural waste, etc. [4]. In India, about $50 \%$ of total human waste is discharged into the rivers and other water bodies without proper treatment [6]. In developing countries, agricultural crop production is practiced on vast land areas in order to meet the food demand of the increasing population. Agrochemicals (fertilizers, pesticides, herbicides, etc.) used in agricultural activities discharge different chemicals, including nutrients (nitrate and phosphate), into the river water. These contaminants originate from both point and non-point sources. Stormwater runoff is another major contamination transport route, which brings treated and untreated sewage, industrial waste, petroleum hydro-chemicals and road dust into the river water [6].

\subsection{Remediation of Polluted River Water}

The remediation of contaminated river water is a burning issue in many developing countries due to the high level of pollution. In addition, the remediation of secondary tributaries is also important for maintaining the higher water quality of channels and streams in rural areas [7]. Polluted river water can be remediated by either in-situ water treatment or pollution control at the source point. Different methods that can be applied for remediation of polluted river water are categorised into physical, chemical, biological, ecological and engineering techniques [8,9], but a single method is not sometimes effective for the purification of heavily contaminated river water. Therefore, hybrid techniques, which combine two or more single methods, are more widely recommended for their efficient treatment.

Engineering and physical treatment processes include mechanical aeration processes, water transfer or diversion and dilution, mechanical algae removal, building hydraulic structures, dredging river sediment, etc. (Table 1). Application of these engineering processes can effectively improve river water and sediment quality, resulting in river restoration. Some of these methods may exert adverse effects, such as the destruction of natural ecosystems and an economic burden from their high capital and maintenance cost [10]. Therefore, these methods should be applied together with biological, chemical and ecological process to accelerate their remediation actions in a sustainable way.

Chemical treatment of polluted water by flocculation, precipitation, oxidation and algaecides can remove suspended solids (SS) and algae. Chemical processes provide a quick remediation of polluted river water [10], but they are temporary and may produce secondary wastes, which can create other hazards. Therefore, flocculation or precipitation processes should focus on the use of environmentally safe chemicals for destruction of suspended solids and algae by chemical treatment. Wang et al. [11] reported that poly aluminium chloride can be used as non-polluting flocculation foam, which can effectively separate algae from water. Adsorptive removal of contaminants by minerals or material surface from river water is commonly observed in hybrid remediation techniques.

There are several biological-ecological treatment technologies available in the literature, such as microbial bioremediation, biofilms, contact oxidation, membrane bioreactor technology, ecological ponds, plant purification treatment, ecological floating beds and constructed wetlands [9]. Polluted river water exhibits odour, turbidity, lack of water transparency, high concentrations of chemical oxygen demand (COD), biological oxygen demand (BOD) and organic and inorganic contaminants. Some studies have used the processes of microorganism, plant and aquatic animal-assisted bioremediation or biodegradation processes to destroy or decompose the organic chemical contaminants, absorb metals (inorganic contaminants) and completely remove the COD, BOD, odour, turbidity and organic and inorganic contaminants from river water [10,12-14]. These processes used both microbial dosing and in-situ microbial techniques. In-situ microbial techniques, which use native bacteria, are more environmentally sustainable and economically feasible. Consequently, in-situ microbial techniques are widely acceptable and applicable and have attracted more attention in wastewater treatment. The most common in-situ microbial techniques used for the treatment of river 
water are the plant-assisted floating bed techniques and constructed wetlands. These techniques can naturally produce bacteria, fungi and fauna, which play important roles in biodegradation of organic contaminants in river water. Biological methods are more environment-friendly, self-sustaining and less expensive than the physical and chemical processes. However, the processes need an extended time, ranging from several months to years for microbial growth and, sometimes, different environmental factors such as temperature and rainfall affect their performance [9]. Some of these technologies require high cost, labour and maintenance as well.

Table 1. Efficiency, advantages, and disadvantages of different physical/engineering-based treatment methods of river water.

\begin{tabular}{|c|c|c|c|c|}
\hline $\begin{array}{l}\text { Treatment } \\
\text { Techniques }\end{array}$ & Process Description & Advantages & Disadvantages & Reference \\
\hline Artificial aeration & $\begin{array}{l}\text { Air flow into river } \\
\text { water increases } \\
\text { microbial diversity and } \\
\text { degrades organic } \\
\text { compounds in water }\end{array}$ & $\begin{array}{c}\text { Effectively improve } \\
\text { water quality, simple } \\
\text { and easy to apply, } \\
\text { sustainable and widely } \\
\text { applicable }\end{array}$ & $\begin{array}{l}\text { Cost intensive during } \\
\text { operation and } \\
\text { maintenance phase }\end{array}$ & {$[9,15]$} \\
\hline $\begin{array}{c}\text { Water } \\
\text { transfer/diversion }\end{array}$ & $\begin{array}{l}\text { Mixing of clean water } \\
\text { with polluted river } \\
\text { water and dilution of } \\
\text { pollution }\end{array}$ & $\begin{array}{l}\text { Improve river water } \\
\text { quality, water supply, } \\
\text { river pollution control, } \\
\text { promote } \\
\text { self-purification } \\
\text { process }\end{array}$ & $\begin{array}{l}\text { Potential destruction of } \\
\text { ecosystem, cost and } \\
\text { labour intensive }\end{array}$ & {$[16,17]$} \\
\hline $\begin{array}{l}\text { Mechanical algae } \\
\text { removal }\end{array}$ & $\begin{array}{l}\text { Removal of algae by } \\
\text { mechanical process }\end{array}$ & $\begin{array}{l}\text { Improve river water } \\
\text { and sediment quality }\end{array}$ & $\begin{array}{c}\text { Cost intensive during } \\
\text { operation and } \\
\text { maintenance phase }\end{array}$ & [18] \\
\hline $\begin{array}{l}\text { Dredging river } \\
\text { sediment }\end{array}$ & $\begin{array}{l}\text { Removal of polluted } \\
\text { sediment by dredging } \\
\text { machine }\end{array}$ & $\begin{array}{l}\text { Improve sediment and } \\
\text { river water } \\
\text { environment }\end{array}$ & $\begin{array}{l}\text { Potential increase of } \\
\text { pollution, cost } \\
\text { intensive mechanical } \\
\text { process }\end{array}$ & {$[9,19]$} \\
\hline $\begin{array}{l}\text { Building hydraulic } \\
\text { structures }\end{array}$ & $\begin{array}{l}\text { Irrigation weirs or } \\
\text { infrastructure built on } \\
\text { the river }\end{array}$ & $\begin{array}{l}\text { Improve river water } \\
\text { quality for irrigation } \\
\text { purposes }\end{array}$ & $\begin{array}{l}\text { Potential destruction of } \\
\text { ecosystem health, cost } \\
\text { intensive }\end{array}$ & {$[20,21]$} \\
\hline Riverbank filtration & $\begin{array}{l}\text { Flow through riverbed } \\
\text { and groundwater } \\
\text { aquifer to the pumping } \\
\text { wells }\end{array}$ & $\begin{array}{l}\text { Remove organic and } \\
\text { inorganic } \\
\text { contaminants through } \\
\text { natural filtration } \\
\text { process }\end{array}$ & Slow process & [22-25] \\
\hline
\end{tabular}

Ecological engineering-based techniques, such as plant purification treatment, ecological floating beds, artificial floating islands and constructed wetlands, have attracted the greatest attention due to their overall economic, environmental and ecological benefits, but these methods demonstrate variable performances to remediate polluted river water $[9,10,26,27]$. The remediation of river water is a critical process which needs the combination of engineering and ecological technologies for successful treatment of river water.

Therefore, further research is needed to improve these remediation processes. The advantages and drawbacks of currently developed methods are to be comparatively discussed to find out the most effective, sustainable, economic and environment friendly processes. Overall, this review discussed the various single and hybrid techniques applied for the remediation of polluted river water along with their efficiencies, advantages and disadvantages. Finally, this review explored the most viable and sustainable techniques for the treatment of river water and how these techniques can be further improved to make them more cost effective and sustainable. 


\section{Engineering and Physical Processes}

\subsection{Aeration}

Aeration, which maximizes the oxygen saturation of water, plays an important role in the remediation of polluted river water and in the effective treatment of wastewater [15]. Aeration techniques are simple, easy to operate, sustainable and widely applicable; however, their implementation can be expensive. Aeration increases the diversity and abundance of microbial communities, which degrade organic compounds in river water and wastewater (Figure 1); however, its performance depends on the rate of aeration and type of aeration approach, such as fixed point aeration and mobile aeration (moving one point to another). Therefore, it should be appropriately applied in water treatment. For example, fixed-point aeration should be applied in sediment-rooted constructed wetland, while mobile aeration should be used in floating bed wetland techniques. Several previous studies have demonstrated that the application of aeration techniques effectively improved the water quality of some rivers, such as the Oeiras River in Portugal, the Emsche River in Germany, the Thames River in the UK and the Homewood Canal in the U.S. [28], and removed the black colour, odour, COD and BOD of river water in Busan (South Korea), Qing River, Guancheng downstream and Shanghai Suzhou River [29].

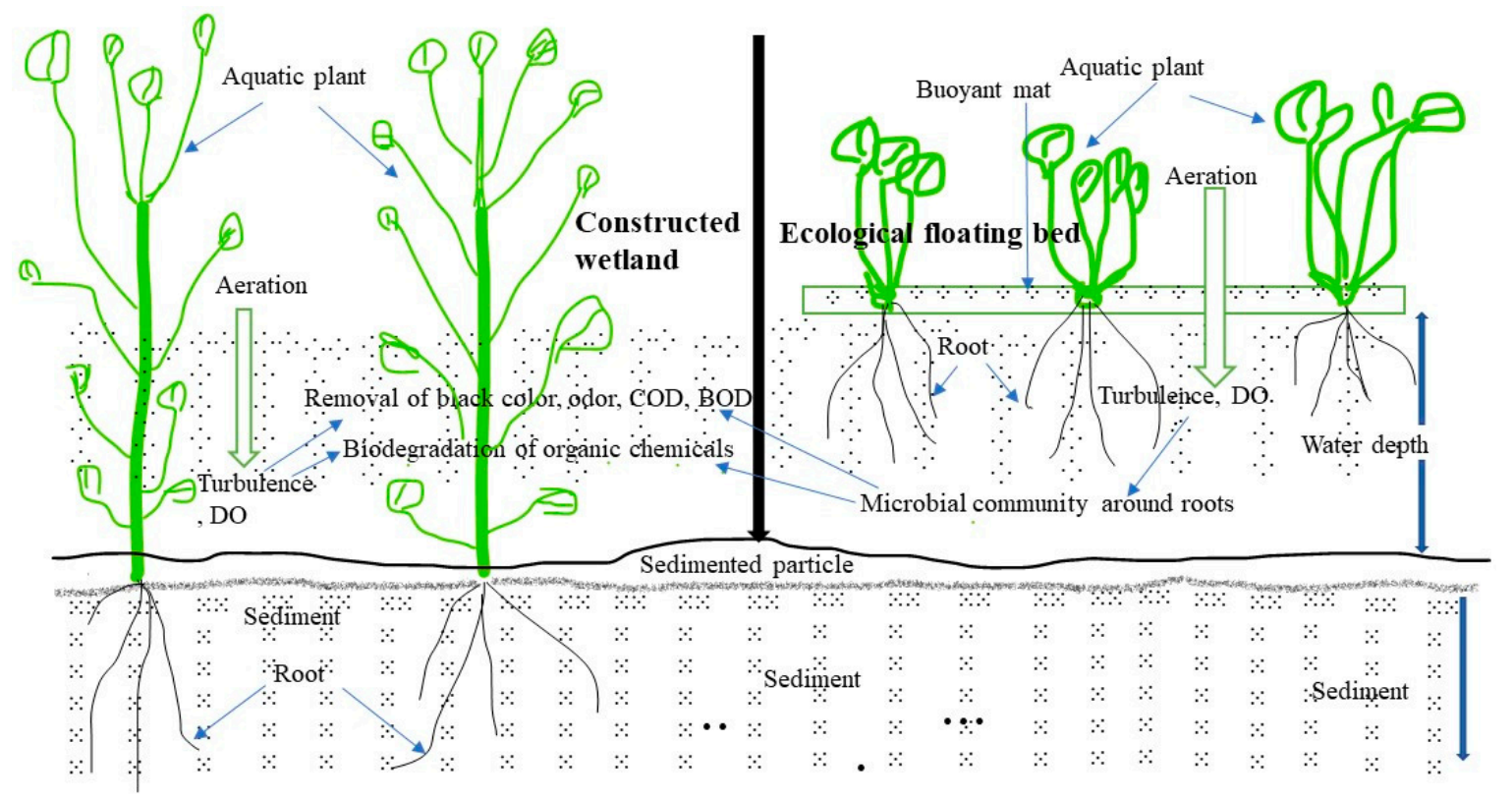

Figure 1. Schematic diagram of aeration technique in ecological treatment of river water.

\subsection{Water Diversion and Water Transfer}

Inter-basin water transfer engineering can change the living style of people, agriculture and industrial growth and the natural environment, and it has been applied in many places in the world [17]. Globally, more than 160 large-scale inter-basin water transfer projects have been constructed in 24 countries, especially in Canada, the United States, the former Soviet Union and India [30]. China is embracing rapid urbanization, industrialization and highly accelerated economic development, which has exploited a large amount of water causing the extensive pollution of water resources. Consequently, China has implemented several small- and large-scale water transfer projects across the country.

Water transfer engineering provides multiple benefits, such as irrigation, water supply, navigation, flood control, power generation [31,32], reducing water crisis, increasing water security [33,34], reducing the concentration of nutrients and phytoplankton $[35,36]$ and improving water quality $[31,32,37]$. The mixing of clean water with polluted river water dilutes the contamination in river water and removes the colour and odour of water. The water diversion technique augments the self-purification 
capacity of the watershed [11,20]. This technology was used in Fuzhou, Zhongshan and other cities in China to remove the contaminants from river water [11]. Water transfers from the Yangtze River to the Lixia River in China clearly showed a positive impact to increase the water quality of the river, especially for sites closer to water intake points [38]. Water quality parameters showed various spatial and temporal variations in patterns within the watershed. This method demonstrated the explicit evidence of reduction in the concentrations of $\mathrm{NH}_{4}{ }^{+}-\mathrm{N}$ and $\mathrm{COD}$ in river water. However, the authors recommended the use of this method as an emergency strategy only to flush out contaminants from the river water due to its quick response [35]. The estimation of diversion scale is the key factor, which depends on the effluent water quality. Sometimes, the task of river water diversion is too large, because it is costly and labour intensive.

The combination of two processes that can more effectively purify the river water are (1) contamination control through wastewater collection and (2) treatment through water transfer/ introduction of clean water into polluted flowing river water [39]. However, these processes exert some environmental effects through the utilization of energy and resources, which should be estimated based on the life cycle assessment process. Therefore, in order to reduce the adverse environmental effects, the optimal integration of the processes should be carried out considering the local pollution concentration and the self-purification coefficient of the river water. Song et al. [16] reported that large amounts of water diversion can decrease the water quality by carrying organisms from one catchment to another. Therefore, it is necessary to estimate the optimal diversion of water. If the water transfer rate is reduced, then the water residence time should be extended, which can augment the degradation of contaminants and improve water quality. Therefore, Martinez et al. [40] developed an engineering model to determine the optimum process for the treatment of polluted river water by pouring a minimum amount of clean water.

\subsection{Hydraulic Structures}

River water, polluted by the dumping of untreated urban sewage, has been used for irrigation and agricultural crop production in some countries such as India [20]. The quality of river water naturally improves by self-purification processes through dilution, sedimentation and biological processes. The construction of hydraulic structures such as irrigation weirs or irrigation infrastructure on the river can improve water quality and make the river water suitable for irrigation [20]. The installation of irrigation weirs on the river reduces water flow velocity but increases hydraulic retention time, which facilitate sedimentation, aeration, sunlight irradiation and anaerobic reactions, resulting in improving water quality. The protection of riverbanks using appropriate materials can enhance the riparian biodiversity and ecosystem restoration process. For example, the use of riprap plants, geotextile combination plants, natural material fabric pads and natural prototypes for riverbank protection could change plant community structure and biodiversity on bank slopes, resulting in the stabilization and protection of riverbank slopes [21].

\subsection{Riverbank Filtration}

Riverbank filtration processes remove organic and inorganic contaminants (COD, $\mathrm{NH}_{4}{ }^{+}-\mathrm{N}$ and $\mathrm{NO}_{3}{ }^{-}-\mathrm{N}$ ) from river water, particularly when water flows through the river-bed and groundwater aquifer to the pumping wells [22-25]. The performance of riverbank filtration in purification of water varies from one region to another because the contaminant removal efficiency of this filtration system depends on the local hydrogeology of aquifers, properties of unsaturated and saturated aquifers, climatic conditions, temperature and river water quality [41]. Other factors that affect the removal efficiency of organic and inorganic pollutants from river water are the redox chemistry, content of organic matter and biogeochemistry of riverbed sediments [42-44].

Some studies demonstrated the high potential of the riverbank filtration system to remove COD, $\mathrm{NH}_{4}{ }^{+}-\mathrm{N}$ and $\mathrm{NO}_{3}-\mathrm{N}$ from river water [41-46]. For example, this process was successful in removing nitrogen $(\mathrm{N})$ and organic pollutants from the Qingyang River water in China, which was polluted by 
reclaimed water [41]. Seasonal variations and water temperature impacted the attenuation of $\mathrm{NO}_{3}{ }^{-}-\mathrm{N}$ through riverbank filtration to groundwater. However, these parameters did not show any effect on the removal of COD. The riverbank filtration system removed nitrogen through biochemical processes in the saturated zone of the Kuihe riverbed in China. However, the unsaturated zone did not show any effect on nitrogen removal [45]. The contrary results were reported by the lab-based column and field studies of Wang et al. [46] at the Kui River in China, which showed that the unsaturated zone and the colmation layer adsorbed and degraded the contaminants of $\mathrm{COD}, \mathrm{NH}_{4}{ }^{+}-\mathrm{N}$ and $\mathrm{NO}_{3}{ }^{-}-\mathrm{N}$ in river water. Therefore, further research is needed to understand the role of the unsaturated zone on nitrogen removal. The contaminants accumulated at the interface between the unsaturated and saturated zones of the aquifer, resulting in the very low concentrations of the contaminants in the saturated zone of groundwater and tube well water.

\section{Ecological Engineering-Based Processes}

Ecological restoration of river ecosystems and treatment of river water can be successfully done by applying riparian wetlands, nitrogen $(\mathrm{N})$ and phosphorus $(\mathrm{P})$ sedimentation and absorption, aeration and ecological floating beds [10]. The most widely used methods for the treatment of river water are constructed floating wetlands, ecological floating islands and other bioremediation technologies. The combination of physical, chemical, biological, ecological and engineering techniques is applied to conduct the ecological restoration of the river ecosystem. For example, Sheng et al. [47] used a hybrid process combining the biological, chemical and engineering processes (aeration) to treat the highly polluted river water at the field level [48]. Their process significantly removed COD, BOD $(>70 \%)$ and odour from the polluted river water.

Although aquatic plants such as Pontederia cordata demonstrated potential for treating river water polluted with $\mathrm{N}, \mathrm{P}$ and organic chemicals, the engineering process of aeration enhanced the water treatment efficiency of this aquatic plant [49]. The seasonal variations and aeration exhibited variable effects on the growth of diverse microbial communities around plant roots and their water purification efficiency. The aquatic plants and moderate aeration exhibited the optimum efficiency for COD, total $\mathrm{N}$ and $P$ removal from water. Aeration exerted the combined effect of turbulence and dissolved oxygen (DO), which was stronger than the individual effect of DO [15]. Some researchers developed the near-natural restoration technique [10] and near-natural river governance model [50] for the treatment of rural river water and enhancing water quality [51].

\subsection{Phytoremediation Process}

Aquatic plants, including algae, demonstrate a high potential to purify river water, wastewater effluents and contaminated water [52]. The tolerant plants, planted in the riverbank, can purify the river water by absorption, adsorption, accumulation and degradation of contaminants. These plants exhibited significant capacity to remove nutrients such as total $\mathrm{N}$ and $\mathrm{P}$ from water bodies [53]. The plant roots provide strong and extensive rhizosphere systems, which facilitate the growth of bacteria and other microorganisms, and secretion of root exudates [54,55]. These microorganisms play a significant role in the removal of organic and inorganic contaminants from wastewater and contaminated water by degradation of organic chemicals and accumulation of nutrients and other metal contaminants. This phytoremediation process can be applied along either the riverbank or wastewater/stormwater discharge point. The technique has low cost and wider community acceptance, irrespective of geographical locations. The most widely used aquatic plants for wastewater treatment (shown in Table 2) are reed (Phragmites australis), water hyacinth (Eichhornia crassipes), alligator weed (Alternanthera philoxeroides) [56], water lettuce (Pistia stratiotes) [55], Whorl-leaf watermilfoil (Myriophyllum verticillatum), pondweed (Potamogeton spp.), cattail (Typha latifolia), duckweed (Lemna gibba) and canna (Canna indica) [57]. These aquatic plants can be used in conventional wastewater treatment processes, constructed wetlands and vegetative biofiltration systems, and in ecological floating bed systems (discussed in next sub-sections). Table 2 describes some examples 
of these plant-based remediation techniques and the plants used in these processes. The success of plant-based remediation technology depends on the coverage of plant growth area. Besides this, plant species have different contaminant removal efficiencies and variable tolerances to contaminant loading rates. Therefore, the selection of an appropriate plant species is an important factor for the maximum performance of plant-based technologies [58].

Table 2. Plant species used in ecological restoration of river ecosystems and remediation of river water.

\begin{tabular}{|c|c|c|c|}
\hline Techniques & Processes or Systems & Plant Species & Reference \\
\hline \multirow{4}{*}{ Wetland } & $\begin{array}{l}\text { Removal of nutrients and } \\
\text { organic matter by aquatic } \\
\text { plants and aeration }\end{array}$ & Pontederia cordata & {$[15,49]$} \\
\hline & \multirow{3}{*}{$\begin{array}{l}\text { Constructed wetlands, } \\
\text { floating bed systems }\end{array}$} & $\begin{array}{l}\text { Reed (Phragmites communis), } \\
\text { E. crassipes (water hyacinth), } \\
\text { A. philoxeroides }\end{array}$ & [56] \\
\hline & & Water lettuce (Pistia stratiotes) & [55] \\
\hline & & $\begin{array}{l}\text { Watermilfoil (M. verticillatum), } \\
\text { pondweed (Potamogeton spp.), } \\
\text { cattail (T. latifolia), duckweed } \\
(\text { L. gibba), canna (C. indica) }\end{array}$ & [57] \\
\hline Hydroponic floating bed & $\begin{array}{l}\text { Removal of TN and TP; } \\
\text { Water spinach performs } \\
\text { better than sticky rice }\end{array}$ & Water spinach, sticky rice & [26] \\
\hline Revetment & $\begin{array}{l}\text { Ecological revetment } \\
\text { plants }\end{array}$ & $\begin{array}{c}\text { Goosegrass, sedges, and water } \\
\text { grasses }\end{array}$ & [59] \\
\hline \multirow{4}{*}{ Floating bed } & $\begin{array}{l}\text { Removal of BOD, COD, } \\
\text { nutrient, metal }\end{array}$ & $\begin{array}{c}\text { Polygonum hydropiper bagen, reeds, } \\
\text { bulrushes }\end{array}$ & [59] \\
\hline & $\begin{array}{l}\text { Multistage floating-bed } \\
\text { system }\end{array}$ & Macrophytes & [60] \\
\hline & $\begin{array}{l}\text { Enhanced ecological } \\
\text { floating beds }\end{array}$ & Canna indica L., Iris pseudacorus L. & {$[61]$} \\
\hline & $\begin{array}{l}\text { Ecological floating bed } \\
\text { for removal of nutrients }\end{array}$ & $\begin{array}{c}\text { Canna indica, Accords calamus, } \\
\text { Cyperus alternifolius, } \\
\text { Vetiveria zizanioides }\end{array}$ & {$[62]$} \\
\hline \multirow{3}{*}{ Floating wetland } & $\begin{array}{l}\text { Endophyte-assisted } \\
\text { floating wetlands }\end{array}$ & Typha domingensis, Leptochloa fusca & {$[63]$} \\
\hline & Floating treatment & Elodea nuttallii & {$[64]$} \\
\hline & wetland & Carex spp., Lythrum salicaria & {$[65]$} \\
\hline
\end{tabular}

\subsection{Constructed Wetlands}

Sediment-rooted plant constructed wetlands exhibit high a potential for the remediation of polluted urban river/creek water [66]. Constructed wetlands combine physical and biogeochemical processes for the effective removal of water pollutants and restoration of the natural river ecosystem (Figure 2). These methods have some advantages over other traditional water treatment processes, which include low running cost, easy maintenance, no secondary pollution, economic and environmental benefits and high efficiency in the restoration of river ecosystems and river water quality [67]. However, they require a large area, have low hydraulic load and exhibit intolerance to heavy pollutant loading rate [9], including the observation of seasonal death and plant diseases [68]. Therefore, living plants are recommended to be replaced by aqua mats and artificial seaweed, which can enhance the growth of microorganisms and overcome the above drawbacks [69]. Given the low removal rate of single constructed wetland, Bai et al. [9] sequentially constructed floating bed wetland, horizontal subsurface flow constructed wetland and surface flow constructed wetland for the treatment of urban river water. The combination of three wetland systems effectively removed COD, $\mathrm{NH}_{4}{ }^{+}-\mathrm{N}, \mathrm{TN}$ (total nitrogen), TP (total phosphorus) and SS from river water. The cost of these multiple treatment systems was much 
lower than the conventional sewage treatment methods. Therefore, constructed wetlands are classified to several types such as surface flow wetland, subsurface flow wetland, horizontal flow wetland, and vertical flow wetland. In subsurface flow wetland, organic pollutants get in contact with bed matrix and biofilm resulting in their aerobic degradation $[70,71]$.

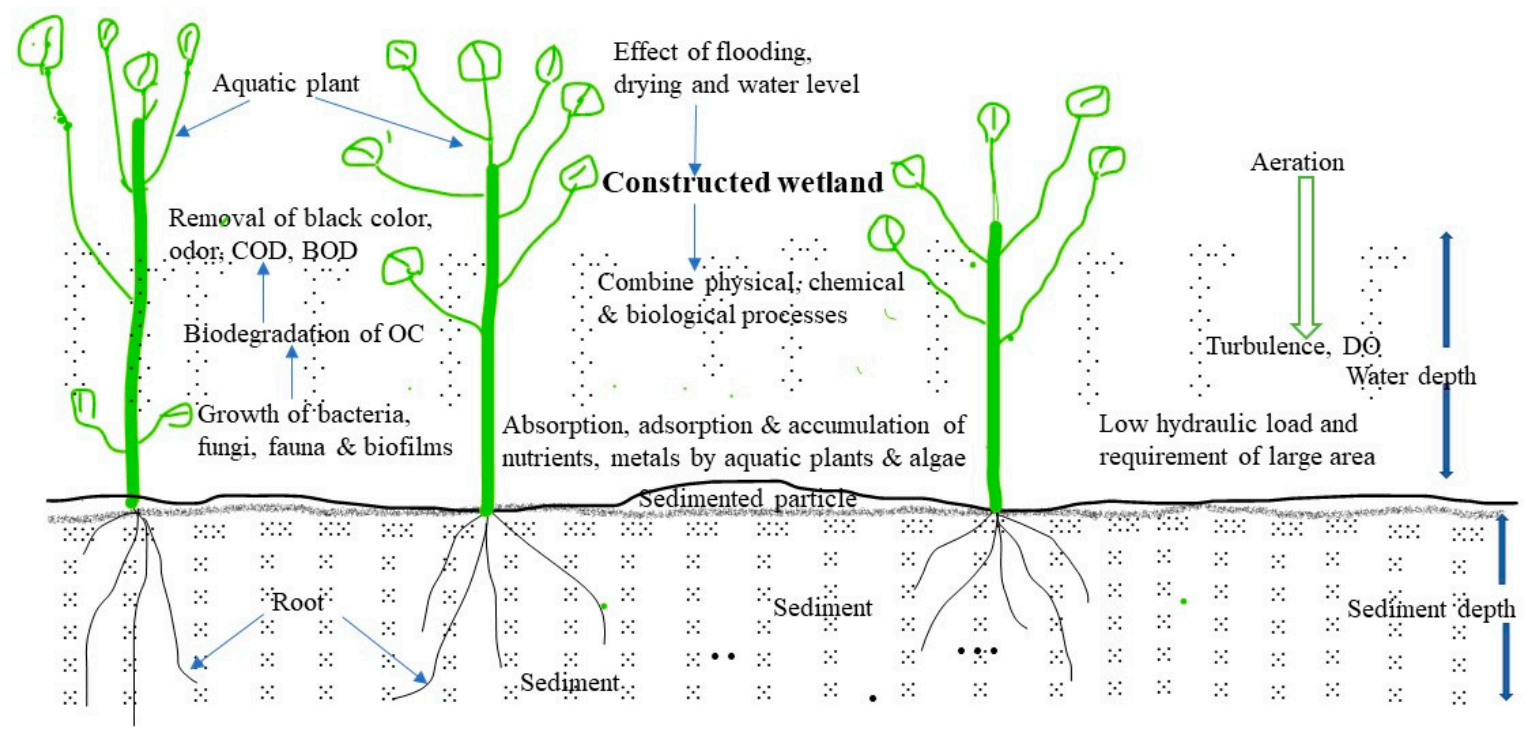

Figure 2. Schematic diagram of constructed wetland with sediment-rooted emergent plants and biofilm for ecological treatment of river water (OC-organic chemicals).

\subsection{Biofilm Reactors}

The biofilm reactors consist of a biomembrane, which is adhered to some media substrate such as the riverbed or a micro-carrier. The manipulation of sediment and wastewater release controls the growth of biomass and microbial diversities in the biofilm reactor. $\mathrm{Xu}$ et al. [72] evaluated the growth of microbial communities in biofilm and the efficiency of biofilm reactors equipped with different bio-fillers to remediate the polluted river water. The treatment system exhibited very high efficiency to remove ammonia nitrogen and COD from water. Aeration of or introduction of DO into the water helps the biofilm techniques to remove the organic and inorganic contaminants by adsorption, degradation and filtration mechanisms. The removal efficiency of contaminants and the structural stability of the biofilm-based systems depend on the hydraulic loading rate, water flow velocity, temperature, and the materials of biofilm [73]. While the technology has been successfully applied in many developed and developing countries [11], there are some drawbacks, such as the potential breaking of the system due to strong water flow, waves [74] and the requirement of extensive construction works [9]. There are several different biofilm technologies used for the remediation of polluted river water, such as gravel contact oxidation, aerated bio-filter biological fluidized bed, artificial packing contact oxidation, thin layer flow method, underground stream purification method and suspended carrier biofilm reactors.

The gravel contact oxidation method was found effective in removing BOD $(72.3 \%)$ and suspended solids $(84.9 \%)$ from polluted water [11]. Takada et al. [75] reported that the batch culture and continuous culture studies using the biofilm attached to the streambed degraded more than $80 \%$ of linear alkylbenzene sulfonates within 2 to 3 hours of travelling time. A gravel contact oxidation system constructed at the riverside could remove BOD, TSS (total suspended solid) and $\mathrm{NH}_{4}{ }^{+}-\mathrm{N}$ by $46 \%$, $71 \%$ and $24 \%$, respectively [76]; however, the removal efficiency was found to be lower $(33.6 \%, 56.3 \%$ and $10.7 \%$, respectively for 5 days) when the system was built under the riverbed of the stream [77]. The riverbed system was easy to operate and less expensive, but the high-water flow rate can reduce the efficiency of the process. Therefore, the system performance depends on the water flow rate and hydraulic retention time. 
The plant-biofilm oxidation ditch demonstrated high performance for remediation of municipal sewage and polluted lake water containing $\mathrm{COD}, \mathrm{NH}_{4}{ }^{+}-\mathrm{N}$ and $\mathrm{PO}_{4}-\mathrm{P}$. The plant root exudates and biofilms in the system played a major role in the treatment of wastewater [78]. The process is cost effective and requires limited land space compared to conventional sewage treatment plants.

Moving bed biofilm reactors are generally used for the treatment of industrial wastewater, secondary sewage effluent, river water and agricultural drainage water, and show high efficiency for the removal of COD and organic chemicals [79,80]. Moving bed biofilm reactors have several advantages, such as ease of operation, insignificant biomass loss, less dependence on temperature, stability in biofilm thickness and low potential for clogging. The heavily polluted river water and wastewater can be remediated by a biological contact oxidation process, which exhibits some advantages, such as being free from bed clogging and having the ability to facilitate sludge bulking. However, its removal efficiency varies with seasonal temperature.

Wang et al. [81] developed a combined technique by using aerators, biofilms and special bacteria in the river to remove COD, BOD, TN, TP and SS. A few more different technologies have been developed to remove N, P, COD, organic matter, turbidity and colour from polluted water, which include bio-ceramics carrier [82], biological filter media, composite packing of pebbles and zeolite for biofilm formation, biological streamer treatment, biocord technology and recirculating sand filter (moderately effective) [83]. Cao et al. [84] showed that the use of filamentous bamboo as a biofilm carrier exhibited high potential in the remediation of polluted river water. They made a hybrid system composed of filamentous bamboo, glucose, air supply and microorganisms. The filamentous bamboo helped to enrich the microbial community in the system, leading to higher bioremediation potential than conventional bio-carriers and phytoremediation techniques.

\subsection{Application of Microbial Agents}

The treatment of polluted river water by engineering-based application of microbial agents/photosynthetic bacteria and microalgae-bacteria media significantly degrades organic matter and removes COD and BOD (about 70\%) [47] and nutrients [85]. Gao et al. [8] observed that the direct mixing of microbial agents with river water increased the DO level to $5.0 \mathrm{mg} / \mathrm{L}$, moderately removed $\mathrm{NH}_{3}-\mathrm{N}, \mathrm{COD}$ and $\mathrm{TP}$ and significantly improved the river water colour. The microbial agents-based techniques are simple in operation, are viable long-term and their application does not need additional constructions. The use of microbial technology in combination with engineering technique exhibits moderate efficiency to remediate polluted river water. The success of this process depends on the selection or natural growth of specific microorganisms and development of low cost and efficient ecological engineering technologies. The use of carriers (AquaMats and semi flexible supports), in combination with aeration, played a vital role in the decontamination of river water [86]. The microbial agents, composed of nitrobacteria, mixed bacteria and humic acid efficiently removed $\mathrm{TN}, \mathrm{TP}, \mathrm{NH}_{4}-\mathrm{N}, \mathrm{COD}$ and turbidity from surface water [87].

\subsection{Ecological Floating Beds}

The floating treatment wetland is a relatively new technology that does not use soil for a plant growth medium [88]. Instead, it uses a synthetic buoyant mat, which acts as a substrate for the growth of plants and roots extending into the water body. Ecological floating beds use ecological processes and they can be used as decentralized in-stream water reclamation technology [6]. Their pollutant removal mechanisms involve phytoremediation (heavy metal uptake by plants), microbial biodegradation of organic chemicals and removal of $\mathrm{N}$ and $\mathrm{P}$ by absorption and sedimentation processes (Figure 3). Although constructed wetlands and ecological floating beds are commonly used for water purification and ecological restoration of river water, the use of constructed wetlands exhibits some constraints due to clogging in the substratum layer and the requirement of a large cover area $[58,89,90]$. By contrast, ecological floating beds are becoming popular for river water treatment because of their cost effectiveness, good removal efficiency and better plant accommodation facility. 
These systems are movable and can be deployed anywhere in the river. They can provide living places for birds and fish [14] but prevent the growth of phytoplankton. Furthermore, they can disrupt the river wave, prevent erosion of the riverbank and promote the growth of vegetation along the riverbank. Overall, these techniques increase the ecological diversity in river ecosystem [90]. Table 3 describes the advantages, disadvantages and removal efficiency of different ecological floating beds for treatment of river water.

Table 3. Efficiency, advantages and disadvantages of different ecological floating beds for remediation of river water.

\begin{tabular}{|c|c|c|c|}
\hline Techniques & Process Description & Advantage/Disadvantage & Reference \\
\hline Plant-based floating bed & $\begin{array}{l}\text { Soil-less plant growth media is } \\
\text { used (polyethylene foam, for } \\
\text { example) like hydroponic } \\
\text { system }\end{array}$ & $\begin{array}{l}\text { Low to moderate performance } \\
\text { for eutrophic river water; } \\
\text { vulnerable to natural disasters }\end{array}$ & {$[62,92]$} \\
\hline Ecological floating bed & $\begin{array}{c}\text { Aquatic plants and microbes } \\
\text { absorb nutrients and degrade } \\
\text { organic chemicals; plants used } \\
\text { include polygonum hydropiper, } \\
\text { reeds, bulrushes, etc. }\end{array}$ & $\begin{array}{c}\text { Efficiently removes nutrients, } \\
\text { organic compounds and metals; } \\
\text { increase DO and transparency; } \\
\text { cost effective; facilitates better } \\
\text { plant accommodation }\end{array}$ & {$[6,59,68,91]$} \\
\hline $\begin{array}{l}\text { Floating wetland/ } \\
\text { artificial floating islands }\end{array}$ & $\begin{array}{l}\text { Floating wetland system with } \\
\text { plant species }\end{array}$ & $\begin{array}{l}\text { Not affected by water } \\
\text { fluctuation and inundation; } \\
\text { efficiently removes nutrients } \\
\text { and organic compounds }\end{array}$ & {$[10,65,93,94]$} \\
\hline Combined floating bed & $\begin{array}{c}\text { Integrated hydrophyte, aquatic } \\
\text { animal, wave-making, } \\
\text { fluorescence inducing } \\
\text { equipment, water cycling \& } \\
\text { aerator } \\
\end{array}$ & $\begin{array}{l}\text { Significantly improved water } \\
\text { quality }\end{array}$ & [14] \\
\hline Hydroponic floating bed & $\begin{array}{l}\text { Water spinach in hydroponic } \\
\text { floating bed systems }\end{array}$ & Efficiently removes nutrients & [26] \\
\hline Hybrid floating bed & $\begin{array}{l}\text { Use of various techniques in } \\
\text { horizontal and vertical space of } \\
\text { water }\end{array}$ & $\begin{array}{l}\text { Efficiently removes nutrients } \\
\text { and increase water transparency; } \\
\text { complex process }\end{array}$ & [95] \\
\hline Multistage floating bed & $\begin{array}{l}\text { Use of macrophytes, aquatic } \\
\text { animals and aquamats ecobase }\end{array}$ & $\begin{array}{l}\text { Effectively removes nutrients, } \\
\text { improves ecological restoration } \\
\text { process; complex process }\end{array}$ & {$[60]$} \\
\hline Enhanced floating bed & $\begin{array}{c}\text { Plant species and substrate are } \\
\text { used }\end{array}$ & $\begin{array}{l}\text { Highly efficient in removing } \\
\text { nutrients }\end{array}$ & {$[61]$} \\
\hline Aqua mats & $\begin{array}{l}\text { Artificial seaweed simulating } \\
\text { natural aquatic plants }\end{array}$ & $\begin{array}{l}\text { High surface area; high growth } \\
\text { of bacteria and algae; effectively } \\
\text { removes nutrients and organic } \\
\text { compounds }\end{array}$ & [69] \\
\hline Endophyte floating bed & $\begin{array}{l}\text { Wetland with T. domingensis, } \\
\text { L. fusca }\end{array}$ & Highly efficient & {$[63,96]$} \\
\hline Stereo floating bed & $\begin{array}{l}\text { Tall fescue plants inoculated } \\
\text { with denitrifying polyphosphate } \\
\text { accumulating microorganisms }\end{array}$ & $\begin{array}{l}\text { Significantly removes nutrients } \\
\text { from eutrophic water }\end{array}$ & [12] \\
\hline
\end{tabular}




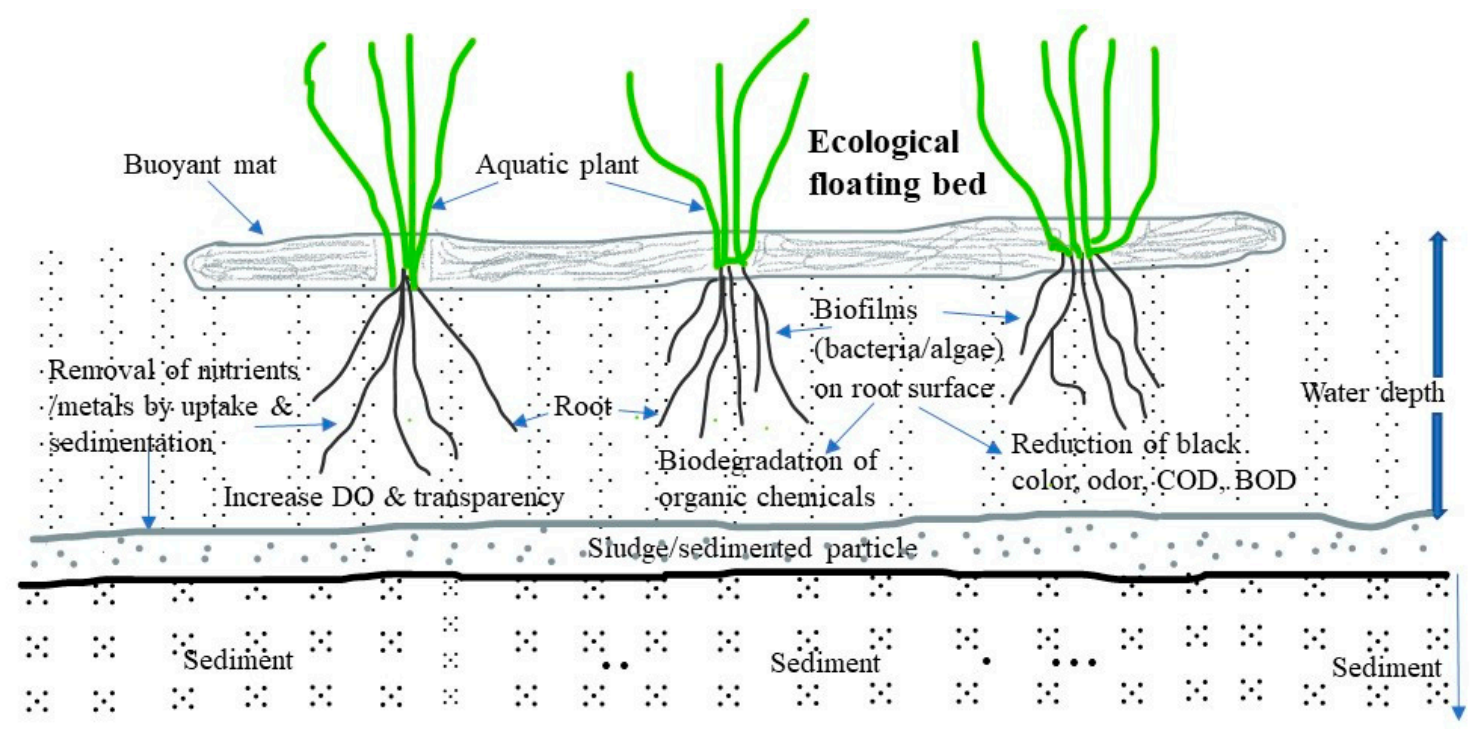

Figure 3. Schematic diagram of ecological floating bed and biofilm for treatment of river water.

\subsubsection{Types of Floating Beds and Their Performance}

Planted floating bed systems effectively remove nutrients and increase DO and transparency in urban river water [91]. Sun et al. [26] treated polluted saline river water using water spinach and sticky rice in hydroponic floating-bed systems. The water spinach floating-bed system exhibited superior performance in removing total $\mathrm{N}(75.2-92.3 \%)$ and $\mathrm{P}(75.2-96.4 \%)$ under variable salinity stress conditions.

Floating beds consisting of specific, highly absorptive, porous materials can show higher pollutant removal efficiency. Therefore, Rao et al. [97] built a double-layer homogeneous porous media artificial ecological floating bed system to investigate the effects of floating beds on water flow pattern and water level distribution. They observed that water flow velocity increases under the floating beds and water level rises in the floating bed region. $\mathrm{Bu}$ and $\mathrm{Xu}$ [62] developed a floating bed using polyethylene foam as the plant growth media and investigated the performance of four different plant species such as Canna indica, Accords calamus, Cyperus alternifolius and Vetiveria zizanioides in removing water contaminants. The system exhibited a low to moderate performance in the removal of COD, TN, TP and Chla (Chlorophyll a) from river water. Wu et al. [61] constructed enhanced ecological floating beds using growth substrate and plant species of Canna indica L. and Iris pseudacorus L. The constructed floating beds made of Canna indica L. and substrate performed better in nutrient removal from water than the beds made of substrate only or Iris pseudacorus L. and substrate.

The multistage floating-bed system consisting of macrophytes, aquatic animals and aquamats ecobase can show higher pollutant removal performance [60]. Chen et al. [60] showed that this technology was effective in nutrient removal, water quality improvement and overall ecological restoration of urban river. Zheng et al. [95] constructed an integrated technique by combining several individual wetland treatment technologies, where different processes were used in horizontal and vertical spaces of the water body. The integrated system was effective in nutrient removal and improving water transparency. The combined application of ecological revetment and an ecological floating bed significantly removed $\mathrm{BOD}(84.76 \%), \mathrm{COD}(57.14 \%), \mathrm{TN}(86.76 \%), \mathrm{NH}_{3}-\mathrm{N}(83.78 \%), \mathrm{NO}_{3}-\mathrm{N}$ $(89.26 \%)$, TP $(94.02 \%)$, TDP (total dissolved phosphorus); $95.89 \%$ ) and heavy metals from surface water [59]. The results indicate that ecological protection and restoration engineering technology can be applied to improve the polluted river water quality.

Artificial floating islands are popular and sustainable technologies for the treatment of river water, particularly for polluted rivers that experience water level fluctuations and waves [10]. These techniques need minor engineering works, but their maintenance is easy and they show significant efficiency in the treatment of polluted river water without any secondary pollution problem [94]. 


\subsubsection{Contaminants Removal Mechanisms in Floating Beds}

The plants and microbes grown in and around the plant roots of floating beds help to remove pathogenic microorganisms, nutrients, heavy metals and organic compounds from water $[98,99]$. The primary removal mechanisms in these plants-microbes interactions are decomposition, assimilation, denitrification, sorption and entrapment in roots and sedimentation [100].

Endophytes present in plant roots actively take part in the phytoremediation process of floating beds. Previous studies observed that endophyte-assisted floating treatment wetlands, planted with Typha domingensis and Leptochloa fusca, exhibited high efficiency for the remediation of sewage, industrial wastewater and polluted river water [63,96]. These processes removed COD and BOD by about $87 \%$ within 4 days [96]. The endophytes in plant roots enhance the remediation potential of the systems, which significantly remove nutrients, organic compounds, heavy metals $(\mathrm{Fe}, \mathrm{Ni}, \mathrm{Mn}, \mathrm{Pb}, \mathrm{Cr})$ and ions ( $\mathrm{Na}, \mathrm{K}, \mathrm{Cl}$ and sulphate). Furthermore, the plant species T. domingensis performed better than L. fusca in the treatment system.

During the removal of nutrients from river water by the Elodea nuttallii aquatic plant, nitrate and ammonium nitrogen were divided into different fractions, such as precipitation in sediment, absorption by Elodea nuttallii and consumption by microbial processes [64]. Their study found that $15 \mathrm{NH}_{4}{ }^{+}$ deposited in sediments at a higher rate than that of $15 \mathrm{NO}_{3}{ }^{-}$, and the plant E. nuttallii assimilated more $15 \mathrm{NH}_{4}{ }^{+}$than $15 \mathrm{NO}_{3}{ }^{-}$. By reducing nutrients, floating bed techniques prevent algae growth in river water. Nutrient removal in floating beds mostly occurs by sedimentation (more than about $60 \%$ ) and plant uptake mechanisms (20.2-29.4\%) [62].

\subsubsection{Factors Affecting Performance of Floating Bed}

Water fluctuation and inundation do not affect the performance of floating treatment wetlands, although they can be rarely and slightly affected by natural disasters such as cyclones or hurricanes $[83,93]$. The selection of proper plant species is important to build highly efficient floating beds for the treatment of polluted river water [62]. For example, the aquatic plant Canna indica performed better than other plant species such as Accords calamus, Cyperus alternifolius and Vetiveria zizanioides for treatment of eutrophic river water. In a study by Pappalardo et al. [65], the plant species of Carex spp. and Lythrum salicaria were used in floating bed wetlands for the treatment of agricultural runoff into surface water. The overall nutrient removal efficiency was about $70-90 \%$, but the bed with Carex spp. performed better than the other. Nutrient removal efficiency of floating beds is primarily governed by the selection of plant species and their microbial community structure ( $\beta$-Proteobacteria, $\alpha$-Proteobacteria and Nitrosomonadaceae) grown in the bed [60]. Other factors that affect their performance include temperature, seasonal variation, reaction contact time and concentration of contaminants [68]. The addition of adsorbent materials (e.g., zeolites, phyllosilicate minerals, red mud adsorbent, activated carbon and bio-sorbents, etc.) in the bed matrix may enhance the removal efficiency of the floating bed systems.

\subsection{Remediation by Aquatic Animals}

Aquatic animals can be applied to the restoration of polluted river water [83]. For example, the freshwater gastropod was used as a bioindicator to estimate the contamination levels of some heavy metals in river water and sediments [101]. Some aquatic animals, such as clams, snails, silver carp, common carp and other filter-feeding fish, are able to reduce concentrations of nutrients, eutrophication and algae in river water, and thus improve the water quality [69]. However, some studies reported that the capability of silver carp fish to control algal biomass is restricted by the toxic effects of the bio-toxins secreted by algae and by the presence of inorganic or organic contaminants in polluted water, which ultimately hamper the performance of this biological treatment system [83]. 


\section{Conclusions and Perspectives}

The random disposal of treated and untreated solid and liquid wastes into water pollutes the receiving river water with nutrients, organic chemicals, metals and nanomaterials. There are different physical, chemical, biological, ecological and engineering methods available for the treatment of polluted river water. The most widely applied engineering and physical processes are aeration, water transfer, mechanical algae removal, building hydraulic structures and dredging river sediment. Aeration is an effective, sustainable and widely applicable technique that plays an important role in increasing the diversity of the microbial community and degrading organic chemicals in river water. Despite the effective remediation of polluted river water, other engineering methods may cause the destruction of the river ecosystem. Therefore, physical engineering techniques should be applied in combination with biological and ecological engineering processes to enhance the ecological restoration process of rivers. Riverbank filtration is a natural, slow and self-sustainable process which removes organic and inorganic contaminants from river water without any adverse effects.

The microbial agents, ecological floating beds, constructed wetlands and biofilm reactor techniques use microorganisms and plant-based bioremediation processes to decompose organic chemicals and remove nutrients and metals from river water. Despite their variable purification performances, these methods have shown high economic, environmental and ecological benefits, have an ease of maintenance and are free from secondary pollution. These techniques combine physical, chemical, biological and ecological engineering processes for the effective removal of water pollutants and the restoration of the river ecosystem.

Biofilm reactors are highly efficient at remediating polluted river water through the growth of microbial communities in biofilms. The efficiency and stability of the biofilm-based systems are dependent on water flow velocity, hydraulic loading rate, temperature, components of media and water depth. The gravel contact oxidation method is applicable to shallow creeks, but not to deep river water. The moving bed biofilm reactors show high efficiency in the removal of COD and organic matter.

The direct mixing of microbial agents with river water moderately removes $\mathrm{NH}_{3}-\mathrm{N}, \mathrm{COD}$ and $\mathrm{TP}$, whereas engineering-based applications of microbial agents significantly degrades organic matter and removes COD, BOD and nutrients. However, their application should be monitored cautiously to avoid microbial contamination.

Ecological floating bed techniques are more widely applicable for the treatment of river water. Water fluctuation, river waves and inundation do not affect their treatment performances. The appropriate selection of plant species is the key influential parameter for them. Inclusion of high capacity adsorbent materials in the matrix of floating mats enhances their contaminant removal efficiency. The hybrid, integrated, sequential and engineering-based floating bed wetlands can demonstrate the maximum water purification efficiency and overcome the drawbacks of single constructed floating beds or wetland.

Aquatic animals have shown contradictory and moderate performances for the restoration of polluted river water. Therefore, this technique is not recommended for the treatment of river water.

Author Contributions: Conceptualization, H.M.A. and R.C.; methodology, H.M.A.; investigation, H.M.A.; resources, H.M.A.; writing-original draft preparation, H.M.A.; writing-review and editing, R.C. and H.M.A.; visualization, H.M.A. All authors have read and agreed to the published version of the manuscript.

Funding: This research received no external funding.

Conflicts of Interest: The authors declare no conflict of interest.

\section{References}

1. Somlyody, L.; Masliev, I.; Kularathna, M. River Basin Water Quality Management Strategies in the Central European Region: An Example of the Nitra River (Slovakia). In Remediation and Management of Degraded River Basins; Novotny, V., Somlyódy, L., Eds.; NATO ASI Series (Environment); Springer: Berlin, Germany, 1995; Volume 3. 
2. Chen, C.H.; Liu, W.L.; Leu, H.G. Sustainable Water Quality Management Framework and a Strategy Planning System for a River Basin. Environ. Manag. 2006, 38, 952-973. [CrossRef] [PubMed]

3. Anawar, H.M.; Safiullah, S.; Yoshioka, T. Environmental exposure assessment of chromium and other tannery pollutants at Hazaribagh area, Dhaka, Bangladesh and health risk. J. Environ. Chem. 2000, 10, 549-556. [CrossRef]

4. Anawar, H.M.; Strezov, V. Transport, fate, and toxicity of the emerging and nanomaterial contaminants in aquatic ecosystems: Removal by natural processes. In Emerging and Nanomaterial Contaminants in Wastewater: Advanced Treatment Technologies, 1st ed.; Mishra, A.K., Anawar, H.M., Nadjib, D., Eds.; Elsevier: Cambridge, CA, USA, 2019.

5. Darwich, T.; Shaban, A.; Hamzé, M. The National Plan for Litani River Remediation. In The Litani River, Lebanon: An Assessment and Current Challenges; Shaban, A., Hamzé, M., Eds.; Water Science and Technology Library, Springer: Cham, Switzerland, 2018; Volume 85.

6. Jamwal, P. Remediation of Contaminated Urban Streams: A Decentralized Ecological Wastewater Treatment Approach. In Water Remediation; Bhattacharya, S., Gupta, A., Gupta, A., Pandey, A., Eds.; Energy, Environment, and Sustainability, Springer: Singapore, 2018; pp. 29-41. Available online: https://www.springer.com/gp/ book/9789811075506\#aboutBook (accessed on 28 July 2019).

7. Nie, Z.Y.; Wu, X.D.; Huang, H.M.; Fang, X.M.; Xu, C.; Wu, J.Y.; Liang, X.Q.; Shi, J.Y. Tracking fluorescent dissolved organic matter in multistage rivers using EEM-PARAFAC analysis: Implications of the secondary tributary remediation for watershed management. Environ. Sci. Pollut. Res. 2016, 23, 8756-8769. [CrossRef] [PubMed]

8. Gao, H.; Xie, Y.B.; Hashim, S.; Khan, A.A.; Wang, X.L.; Xu, H.Y. Application of Microbial Technology Used in Bioremediation of Urban Polluted River: A Case Study of Chengnan River, China. Water 2018, 10, 643. [CrossRef]

9. Bai, X.Y.; Zhu, X.F.; Jiang, H.B.; Wang, Z.Q.; He, C.G.; Sheng, L.X.; Zhuang, J. Purification effect of sequential constructed wetland for the polluted water in urban river. Water 2020, 12, 1054. [CrossRef]

10. Ge, P.L.; Chen, M.; Zhang, L.C.; Song, Y.J.; Mo, M.H.; Wang, L.Y. Study on water ecological restoration Technology of river. IOP Conf. Ser. Earth Environ. Sci. 2019, 371, 032025.

11. Wang, J.; Liu, X.D.; Lu, J. Urban River Pollution Control and Remediation. Procedia Environ. Sci. 2012, 13, 1856-1862. [CrossRef]

12. Zhao, F.L.; Zhang, S.D.; Ding, Z.L.; Aziz, R.; Rafiq, M.T.; Li, H.; He, Z.L.; Stoffella, P.J.; Yang, X.E. Enhanced Purification of Eutrophic Water by Microbe-Inoculated Stereo Floating Beds. Pol. J. Environ. Stud. 2013, 22, 957-964.

13. Cui, N.X.; Chen, G.F.; Liu, Y.Q.; Zhou, L.; Cai, M.; Song, X.F.; Zou, G.Y. Comparison of two different ecological floating bio-reactors for pollution control in hyper-eutrophic freshwater. Sci. Rep. 2018, 8, 14306. [CrossRef]

14. Zheng, L.G.; Wang, H.P. Effect of combined ecological floating bed for eutrophic lake remediation. Presented AIP Conf. Proc. 2017, 1839, 020058. Available online: https://aip.scitation.org/doi/pdf/10.1063/1.4982423 (accessed on 8 May 2017).

15. Zhang, L. A Study of Polluted River Remediation by Aeration. In Proceedings of the 6th International Asia Conference on Industrial Engineering and Management Innovation; Qi, E., Ed.; Atlantis Press: Paris, France, 2016; pp. 451-461.

16. Song, W.W.; Xu, Q.; Fu, X.Q.; Zhang, P.; Pang, Y.; Song, D.H. Research on the Relationship between Water Diversion and Water Quality of Xuanwu Lake, China. Int. J. Environ. Res. Pub. He. 2018, 15, 1262. [CrossRef] [PubMed]

17. Davies, B.R.; Thoms, M.; Meador, M. An assessment of the ecological impacts of inter-basin water transfers, and their threats to river basin integrity and conservation. Aquat. Conserv. 2010, 2, 325-349. [CrossRef]

18. Middlebrooks, E.J.; Porcella, D.B.; Gearheart, R.A.; Marshall, G.R.; Reynolds, J.H.; Grenney, W.J. Review paper: Evaluation of Techniques for Algae Removal from Wastewater Stabilization Ponds. 1974. Available online: https://digitalcommons.usu.edu/cgi/viewcontent.cgi?referer=https://www.google.com. hk/\&httpsredir=1\&article=1202\&context=water_rep (accessed on 22 July 2019).

19. Kondratyev, S. A system for ecological and economic assessment of the use, preservation and restoration of urban water bodies: St Petersburg as a case study. Intern. Assoc. Hydrol. Sci. 2003, 281, 327-333.

20. Ensink, J.H.J.; Scott, C.A.; Brooker, S.J. Sewage disposal in the Musi-River, India: Water quality remediation through irrigation infrastructure. Irrig. Drainage Syst. 2010, 24, 65-77. [CrossRef] 
21. Radspinner, R.R.; Diplas, P.; Lightbody, A.F.; Sotiropoulos, F. River training and ecological enhancement potential using in-stream structures. J. Hydraulic Eng. 2010, 136, 967-980. [CrossRef]

22. Hu, B.; Teng, Y.G.; Zhai, Y.Z.; Zuo, R.; Li, J.; Chen, H.Y. Riverbank filtration in China: A review and perspective. J. Hydrol. 2016, 541, 914-927. [CrossRef]

23. Ray, C.; Grischek, T.; Schubert, J.; Wang, J.Z.; Speth, T.F. A perspective of riverbank filtration. J. Am. Water Works Ass. 2002, 94, 149-160. [CrossRef]

24. Ray, C. Worldwide potential of riverbank filtration. Clean Tech. Environ. Policy 2008, 10, 223-225. [CrossRef]

25. Tyagi, S.; Dobhal, R.; Kimothi, P.C.; Adlakha, L.K.; Singh, P.; Uniyal, D.P. Studies of river water quality using riverbank filtration in Uttarakhand, India. Water Qual. Expo. Health 2013, 5, 139-148. [CrossRef]

26. Sun, S.L.; Sheng, Y.Q.; Zhao, G.Q.; Li, Z.R.; Yang, J. Feasibility assessment: Application of ecological floating beds for polluted tidal river remediation. Environ. Monit. Assess. 2017, 189, 609. [CrossRef]

27. Kamble, R.; Patil, D. Artificial floating island: Solution to river water pollution in India. Case study: Rivers in Pune City. In Presented at 2012 International Conference on Environmental, Biomedical and Biotechnology (IPCBEE); IACSIT Press: Jurong West, Singapore, 2012; Volume 41, pp. 136-140. Available online: http: //www.ipcbee.com/vol41/028-ICEBB2012-R018.pdf (accessed on 19 February 2020).

28. Rogers, G.R. Water quality management at Santa Cruz Harbor. Aire-O2 News 2000, 7, 4-5.

29. Wang, C.X.; Ling, H.; Shi, K.H. Oxygen Restoration of Polluted Water with Pure Oxygen Aeration. Shanghai Environ. Sci. 1999, 18, 411-413. (In Chinese). Available online: https://en.cnki.com.cn/Article_en/CJFDTotalSHHJ199909012.htm (accessed on 26 August 2020).

30. Wang, X.L. Famous water transfer project in river basin. Water Resour. Electr. Power 2004, 30, 1-25.

31. Xie, X.Y.; Qian, X.; Zhang, Y.C.; Qian, Y.; Tian, F. Effect on Chaohu Lake water environment of water transfer from Yangtze River to Chaohu Lake. Res. Environ. Sci. 2009, 22, 897-901. (In Chinese)

32. Hu, L.M.; Hu, W.P.; Zhai, S.H.; Wu, H.Y. Effects on water quality following water transfer in lake Taihu, China. Ecol. Eng. 2010, 36, 471-481. [CrossRef]

33. Gibbins, C.N.; Soulsby, C.; Jeffries, M.J.; Acomley, R.M. Developing ecological acceptable river flow regimes: A case study of Kielder Reservoir and the Kielder water transfer system. Fisheries Manag. Ecol. 2001, 8, 463-485. [CrossRef]

34. Chen, D.; Webber, M.; Finlayson, B.; Barnett, J.; Chen, Z.Y.; Wang, M. The impact of water transfers from the lower Yangtze River on water security in Shanghai. Appl. Geog. 2013, 45, 303-310. [CrossRef]

35. Hu, W.P.; Zhai, S.J.; Zhu, Z.C.; Han, H.J. Impacts of the Yangtze River water transfer on the restoration of Lake Taihu. Ecol. Eng. 2008, 34, 30-49. [CrossRef]

36. Zhai, S.J.; Hu, W.P.; Zhu, Z.C. Ecological impacts of water transfer on lake Taihu from the Yangtze River, China. Ecol. Eng. 2010, 36, 406-420. [CrossRef]

37. Li, Y.P.; Acharya, K.; Yu, Z.B. Modeling impacts of Yangtze River water transfer on water ages in lake Taihu, China. Ecol. Eng. 2011, 37, 325-334. [CrossRef]

38. Ma, X.X.; Wang, L.C.; Wu, H.; Li, N.; Ma, L.; Zeng, C.F. Impact of Yangtze River Water Transfer on the Water Quality of the Lixia River Watershed, China. PLoS ONE 2015, 10, e0119720. [CrossRef] [PubMed]

39. Zhang, W.L.; Fang, S.Q.; Li, Y.; Dong, F.; Zhang, C.; Wang, C.; Wang, P.F.; Xiong, W.; Hou, X. Optimizing the integration of pollution control and water transfer for contaminated river remediation considering life-cycle concept. J. Clean. Product. 2019, 236, 117651. [CrossRef]

40. Martinez, A.; Alvarez-Vázquez, L.J.; Vázquez-Méndez, M.E.; Vilar, M.A. Optimal Control for River Pollution Remediation. In Numerical Mathematics and Advanced Applications 2009; Kreiss, G., Lötstedt, P., Målqvist, A., Neytcheva, M., Eds.; Springer: Berlin, Germany, 2010.

41. Pan, W.; Huang, Q.; Huang, G. Nitrogen and organics removal during riverbank filtration along a reclaimed water restored river in Beijing, China. Water 2018, 10, 491. [CrossRef]

42. Laverman, A.M.; Garnier, J.A.; Mounier, E.M.; Roose-Amsaleg, C.L. Nitrous oxide production kinetics during nitrate reduction in river sediments. Water Res. 2010, 44, 1753-1764. [CrossRef]

43. Maeng, S.K.; Sharma, S.K.; Lekkerkerker-Teunissen, K.; Amy, G.L. Occurrence and fate of bulk organic matter and pharmaceutically active compounds in managed aquifer recharge: A review. Water Res. 2011, 45, 3015-3033. [CrossRef]

44. Hayakawa, A.; Ikeda, S.; Tsushima, R.; Ishikawa, Y.; Hidaka, S. Spatial and temporal variations in nutrients in water and riverbed sediments at the mouths of rivers that enter Lake Hachiro, a shallow eutrophic lake in Japan. Catena 2015, 133, 486-494. [CrossRef] 
45. Wu, Y.G.; Hui, L.; Wang, H.; Li, Y.F.; Zeng, R. Effectiveness of riverbank filtration for removal of nitrogen from heavily polluted rivers: A case study of Kuihe River, Xuzhou, Jiangsu, China. Environ. Geol. 2007, 52, 19-25. [CrossRef]

46. Wang, C.; Wang, P.F.; Hu, X. Removal of CODCr and Nitrogen in Severely Polluted River Water by Bank Filtration. Environ. Technol. 2007, 28, 649-657. [CrossRef]

47. Sheng, Y.Q.; Chen, F.Z.; Sheng, G.Y.; Fu, J.M. Water quality remediation in a heavily polluted tidal river in Guangzhou, south China. Aquat. Ecosyst. Health Manag. 2012, 15, 219-226. [CrossRef]

48. Sheng, Y.Q.; Qu, Y.X.; Ding, C.F.; Sun, Q.Y.; Mortimer, R.J.G. A combined application of different engineering and biological techniques to remediate a heavily polluted river. Ecol. Eng. 2013, 57, 1-7. [CrossRef]

49. Gu, D.G.; Xu, H.; He, Y.; Zhao, F.; Huang, M.S. Remediation of urban river water by Pontederia Cordata combined with artificial aeration: Organic matter and nutrients removal and root-adhered bacterial communities. Int. J. Phytoremediat 2015, 17, 1105-1114. [CrossRef]

50. Yang, T.-M.; Hsu, N.-S.; Chiu, C.-C.; Wang, H.-J. Applying the Taguchi method to river water pollution remediation strategy optimization. Int. J. Environ. Res. Public Health 2014, 11, 4108-4124. [CrossRef] [PubMed]

51. Samal, K.; Kar, S.; Trivedi, S. Ecological floating bed (EFB) for decontamination of polluted water bodies: Design, mechanism and performance. J. Environ. Manage. 2019, 251, 109550. [CrossRef] [PubMed]

52. Anawar, H.M.; Garcia-Sanchez, A.; TariKul Alam, M.; Majibur Rahman, M. Phytofiltration of water polluted with arsenic and heavy metals. Int. J. Environ. Pollut. 2008, 33, 292-312. [CrossRef]

53. Tong, C.H.; Yang, X.E.; Pu, P.M. Effects and Mechanism of Hydrophytes on Control of Release of Nutrient Salts in Lake Sediment. J. Agro Environ. Sci. 2003, 22, 673-676. (In Chinese)

54. Steenhoudt, O.; Vanderleyden, J. Azospirillum, a free-living nitrogen-fixing bacterium closely associated with grasses: Genetic, biochemical and ecological aspects. FEMS Microbiol. Rev 2000, 24, 487-506. [CrossRef]

55. Zimmels, Y.; Kirzhner, F.; Malkovskaja, A. Application and features of cascade aquatic plants system for sewage treatment. Ecol. Eng. 2008, 34, 147-161. [CrossRef]

56. Sato, K.; Sakui, H.; Sakai, Y.; Tanaka, S. Long-term experimental study of the aquatic plant system for polluted river water. Water Sci. Technol. 2008, 46, 217-224. [CrossRef]

57. Allam, A.; Tawfik, A.; El-Saadi, A.; Negm, A.M. Potentials of using duckweed (Lemna gibba) for treatment of drainage water for reuse in irrigation purposes. Desalin Water Treat 2016, 57, 459-467. [CrossRef]

58. Zhao, Y.; Yang, Z.F.; Xia, X.H.; Wang, F. A shallow lake remediation regime with Phragmites australis: Incorporating nutrient removal and water evapotranspiration. Water Res. 2012, 46, 5635-5644. [CrossRef]

59. Lv, J.; Xu, J.L.; Wang, H.X.; Li, W.; Liu, X.J.; Yao, D.F.; Lu, Y.; Zheng, X.X. Study on ecological protection and rehabilitation technology of a reservoir-type water source in the northeastern region of China. Hum. Ecol. Risk Assess. 2019, 25, 1802-1815. [CrossRef]

60. Chen, Y.H.; Zhang, Y.; Huang, M.S.; Zhang, Y.F.; Zhao, F.; Luo, J.H. Ecological restoration by a multistage floating-bed system in a eutrophic urban river, China. Appl. Mech. Mater. 2012, 157-158, 945-949. [CrossRef]

61. Wu, Q.; Hu, Y.; Li, S.Q.; Peng, S.; Zhao, H.B. Microbial mechanisms of using enhanced ecological floating beds for eutrophic water improvement. Bioresour. Technol. 2016, 211, 451-456. [CrossRef]

62. Bu, F.P.; Xu, X.Y. Planted floating bed performance in treatment of eutrophic river water. Environ. Monit. Assess. 2013, 185, 9651-9662. [CrossRef] [PubMed]

63. Shahid, M.J.; Tahseen, R.; Siddique, M.; Ali, S.; Iqbal, S.; Afzal, M. Remediation of polluted river water by floating treatment wetlands. Water Supply 2019, 19, 967-977. [CrossRef]

64. Wang, H.; Li, Z.K.; Han, H.Y. Comparison of different ecological remediation methods for removing nitrate and ammonium in Qinshui River, Gonghu Bay, Taihu Lake. Environ. Sci. Pollut. Res. 2017, 24, 1706-1718. [CrossRef]

65. Pappalardo, S.E.; Ibrahim, H.M.S.; Cerinato, S.; Borin, M. Assessing the water-purification service in an integrated agricultural wetland within the Venetian Lagoon drainage system. Mar. Freshw. Res. 2017, 68, 2205-2215. [CrossRef]

66. Anawar, H.M.; Ahmed, G.; Strezov, V. Long-term performance and feasibility of using constructed wetlands for treatment of emerging and nanomaterial contaminants in municipal and industrial wastewater. In Emerging and Nanomaterial Contaminants in Wastewater: Advanced Treatment Technologies, 1st ed.; Mishra, A.K., Anawar, H.M., Nadjib, D., Eds.; Elsevier: Cambridge, CA, USA, 2019; pp. 63-81. 
67. Konnerup, D.; Koottatep, T.; Brix, H. Treatment of domestic wastewater in tropical, subsurface flow constructed wetlands planted with Canna and Heliconia. Ecol. Eng. 2009, 35, 248-257. [CrossRef]

68. Deng, Y.; Ni, F.Q. Review of Ecological Floating Bed Restoration in Polluted Water. J. Water Resour. Prot. 2013, 5, 1203-1209. [CrossRef]

69. Xiao, L.J.; Ouyang, H.; Li, H.M.; Chen, M.R.; Lin, Q.Q.; Han, B.P. Enclosure study on phytoplankton response to stocking of silver carp (Hypophthalmichthys molitrix) in a eutrophic tropical reservoir in South China. Int. Rev. Hydrobiol. 2010, 95, 428-439. [CrossRef]

70. Samal, K.; Dash, R.R.; Bhunia, P. A comparative study of macrophytes influence on performance of hybrid vermifilter for wastewater treatment. J. Environ. Chem. Eng. 2018, 6, 4714-4726. [CrossRef]

71. Vymazal, J. Removal of nutrients in various types of constructed wetlands. Sci. Total Environ. 2007, 380, 48-65. [CrossRef] [PubMed]

72. Xu, X.Y.; Feng, L.J.; Zhu, L.; Xu, J.; Ding, W.; Qi, H.Y. Biofilm formation and microbial community analysis of the simulated river bioreactor for contaminated source water remediation. Environ. Sci. Pollut. Res. 2012, 19, 1584-1593. [CrossRef]

73. Paulsen, J.E.; Oppen, E.; Bakke, R. Biofilm morphology in porous media, a study with microsopic and image techniques. Water Sci. Technol. 1997, 36, 1-9. [CrossRef]

74. Li, X.Y.; Chu, H.P. Membrane bioreactor for the drinking water treatment of polluted surface water supplies. Water Res. 2003, 37, 4781-4791. [CrossRef]

75. Takada, H.; Mutoh, K.; Tomita, N.; Miyadzu, T.; Ogura, N. Rapid removal of linear alkylbenzene sulfonates (LAS) by attached biofilm in an urban shallow stream. Water Res. 1994, 28, 1953-1960. [CrossRef]

76. You, J.Y.; Cao, Q.W.; Lin, Z.Y.; Chen, J.Z. Relationship between engineering design parameters and water quality for constructed cobble bed in Guandu. J. Environ. Protec. 2006, 29, 73-90. (In Chinese)

77. Juang, D.F.; Tsai, W.P.; Liu, W.K.; Lin, J.H. Treatment of polluted river water by a gravel contact oxidation system constructed under riverbed. Int. J. Environ. Sci. Technol. 2008, 5, 305-314. [CrossRef]

78. Ruan, X.; Xue, Y.; Wu, J.; Ni, L.; Sun, M.; Zhang, X. Treatment of polluted river water using pilot-scale constructed wetlands. Bull. Environ. Contaminat. Toxicol. 2006, 76, 90-97. [CrossRef]

79. Ateia, M.; Nasr, M.; Yoshimura, C.; Fujii, M. Organic Matter Removal from Saline Agricultural Drainage Wastewater Using a Moving Bed Biofilm Reactor. Water Sci. Technol. 2015, 72, 1327-1333. [CrossRef]

80. Chiemchaisri, C.; Panchawaranon, C.; Rutchatanunti, S.; Kludpiban, A.; Ngo, H.; Vigneswaran, S. Development of floating plastic media filtration system for water treatment and wastewater reuse. J. Environ. Sci. Health 2003, 38, 2359-2368. [CrossRef]

81. Wang, S.M.; Wang, B.Z.; Jin, W.B.; Cao, X.D.; Bo, T. In-Situ Remediation Technology for Polluted Water in Urban River. Urban Environ. Urban Ecol. 2008, 21, 1-4. (In Chinese)

82. Cao, Y.; Sun, C.J. Application of Ecological Floating Beds to Water Restoration and Its Design. Environ. Sci. Technol. 2009, 32, 121-124. (In Chinese)

83. Ateia, M.; Yoshimura, C.; Nasr, M. In-situ Biological Water Treatment Technologies for Environmental Remediation: A Review. J. Bioremediat. Biodegrad. 2016, 7, 1-5. [CrossRef]

84. Cao, W.P.; Zhang, H.H.; Wang, Y.M.; Pan, J.Z. Bioremediation of polluted surface water by using biofilms on filamentous bamboo. Ecol. Eng. 2012, 42, 146-149. [CrossRef]

85. Liu, J.Z.; Wu, Y.H.; Wu, C.X.; Muylaert, K.; Vyverman, W.; Yu, H.Q.; Muñoz, R.; Rittmann, B. Advanced nutrient removal from surface water by a consortium of attached microalgae and bacteria: A review. Bioresour. Technol. 2017, 241, 1127-1137. [CrossRef] [PubMed]

86. Wu, W.Z.; Liu, Y.; Zhu, Q.; Wei, C.J.; Wang, J.L. Remediation of polluted river water by biological contact oxidation process using two types of carriers. Int. J. Environ. Pollut. 2009, 38, 223-234. [CrossRef]

87. Shan, M.J.; Wang, Y.Q.; Shen, X. Study on bioremediation of eutrophic lake. J. Environ. Sci. 2009, 21, S16-S18. [CrossRef]

88. Faulwetter, J.; Burr, M.D.; Cunningham, A.B.; Stewart, F.M.; Camper, A.K.; Stein, O.R. Floating treatment wetlands for domestic wastewater treatment. Water Sci. Technol. 2011, 64, 2089-2095. [CrossRef]

89. Iamchaturapatr, J.; Yi, S.W.; Rhee, J.S. Nutrient removals by 21 aquatic plants for vertical free surface-flow (VFS) constructed wetland. Ecol. Eng. 2007, 29, 287-293. [CrossRef]

90. Knowles, P.; Dotro, G.; Nivala, J.; García, J. Clogging in subsurface-flow treatment wetlands: Occurrence and contributing factors. Ecol. Eng. 2011, 37, 99-112. [CrossRef] 
91. Ning, D.L.; Huang, Y.; Pan, R.S.; Wang, F.Y.; Wang, H. Effect of eco-remediation using planted floating bed system on nutrients and heavy metals in urban river water and sediment: A field study in China. Sci. Total Environ. 2014, 485-486, 596-603. [CrossRef] [PubMed]

92. Li, X.N.; Song, H.L.; Li, W.; Lu, X.W.; Nishimura, O. An integrated ecological floating bed employing plant, freshwater clam and biofilm carrier for purification of eutrophic water. Ecol. Eng. 2010, 36, 382-390. [CrossRef]

93. Headley, T.R.; Tanner, C.C. Application of Floating Wetlands for Enhanced Stormwater Treatment: A Review; Auckland Regional Council Technical Report TR2008/030: Auckland, New Zealand, 2006. Available online: http://www.aucklandcity.govt.nz/council/documents/technicalpublications/TP324\%20-\%20Floating\% 20Wetland\%20Review-Final.pdf (accessed on 23 March 2020).

94. Headley, T.R.; Tanner, C.C. Constructed wetlands with floating emergent macrophytes: An innovative stormwater treatment technology. Critical Rev. Environ. Sci. Technol. 2012, 42, 2261-2310. [CrossRef]

95. Zheng, Z.; Zhang, W.; Luo, X.Z.; Wang, S.B.; Yang, X.Y.; He, J.; Nie, E. Design and application of plant ecological space technology in water eutrophication Control. J. Environ. Eng. 2019, 145, 04018142. [CrossRef]

96. Ijaz, A.; Iqbal, Z.; Afzal, M. Remediation of sewage and industrial effluent using bacterially assisted floating treatment wetlands vegetated with Typha domingensis. Water Sci. Technol. 2016, 74, 2192-2201. [CrossRef]

97. Rao, L.; Qian, J.; Ao, Y.H. Influence of artificial ecological floating beds on river hydraulic characteristics. J. Hydrodyn. 2014, 26, 474-481. [CrossRef]

98. Kadlec, R.H.; Wallace, S. Treatment Wetlands, 2nd ed.; CRC Press: Boca Raton, FL, USA, 2009. Available online: https://sswm.info/sites/default/files/reference_attachments/KADLEC\%20WALLACE\% 202009\%20Treatment\%20Wetlands\%202nd\%20Edition_0.pdf (accessed on 12 April 2020).

99. Billore, S.K.; Prashant; Sharma, J.K. Treatment performance of artificial floating reed beds in an experimental mesocosm to improve the water quality of river Kshipra. Water Sci. Technol. 2009, 60, 2851-2859. [CrossRef]

100. Ijaz, A.; Imran, A.; ul Haq, M.A.; Khan, Q.M.; Afzal, M. Phytoremediation: Recent advances in plant-endophytic synergistic interactions. Plant Soil 2016, 405, 179-195. [CrossRef]

101. Li, D.L.; Pi, J.; Zhang, T.; Tan, X.; Fraser, D.J. Evaluating a 5-year metal contamination remediation and the biomonitoring potential of a freshwater gastropod along the Xiangjiang River, China. Environ. Sci. Pollut. Res. 2018, 25, 21127-21137. [CrossRef] 